\title{
Unsettling trends in collective bargaining today
}

\author{
Raluca Dimitriul,a \\ The Bucharest University of Economic Studies, Romania
}

\begin{abstract}
A bstract: Today, there is virtually no legal system that does not enshrine collective bargaining - as the foundation of a balance of forces in the labour market. At each level it is conducted (international - European - national - sector local - unit), it determines the way labour relations are regulated and gives workers the opportunity to express themselves, through solidarity, with a unique voice Through collective bargaining, employees have the opportunity, by uniting their bargaining power to counter-balance the superior power of the employer, to determine the acceptance of (some of) the demands and the contractual regulation of fair wages and working conditions, in relation to the possibilities and needs of each party. Currently, one cannot but notice that collective bargaining has indeed its limits, some circumstantial, others permanent. Collective bargai ning takes place increasingly more timid and in rather marginal areas, its results covering a smaller number of empl oyees. As traditional expression of the solidarity between workers, collective bargaining - while this solidarity displays signs of dissolution - has diminished its strength and shows a centrifugal, decentral ising tendency.The paper presents some of the circumstances that can be considered responsible for the tendency to compress collective bargaining at all levels. Certain causes are therefore analyzed: gl obalization, detailed legalization, the competitive relationship between employees, the consumers' pressure or the opposition of the individual employee.
\end{abstract}

K eywords: Labour law, collective bargaining, European Union, collective agreement

\section{J EL codes: $K 31$}

${ }^{1}$ Corresponding author: Raluca Dimitriu, Law Department University of Economic Studies, Romania, Piata Romana no. 6 Bucharest, email address: raluca.dimitriu@cig.asero 


\section{Preliminary considerations}

Sometimes called "industrial relations law", collective labour law deals with that component of labour law governing relationships - alternating cooperation and conflict - between the social partners, including their rights and obligations regarding information and mutual consultation, collective bargaining as well as the pressure tools that are available to workers during the course of these negotiations. In principle, such a component of labour law allows workers to use the various freedoms (freedom of association, freedom to strike, freedom of expression etc.) to outsource divergences beyond the workplace itself. Some authors operate a certain distinction between "collective labour law" and "the collective dimension of labour law" (Hendrickx, 2010: 65), but in all approaches the essential component of collective labour law is collective bargaining.

Indeed, since early twentieth century collective bargaining has been the cornerstone of labour law. Labour law is inextricably linked to collective bargaining. In France, for example, its birth was marked by the process by which, alongside flourishing state interventionism, collective autonomy gradually absorbed individual autonomy, the union substituting itself to the individual employee as interlocutor for the employer, collective bargaining supplementing and strengthening the individual one (Adam, 2005: 136).

But the role of pioneer in the field of collective bargaining belongs to Germany. This is due - among other things - to a particular feature of national competition law. Germany did not know anti-competition legislation which was dominating trade, for example, in Anglo-Saxon countries. Monopolistic restrictions were recognized as legal and cartel type practices were not considered anticompetitive, but just expressions of the freedom of contract. In this context, unionization and collective bargaining had been accepted more easily (Däubler in Rigaux et al., 2014: 60). They did not collide (as in the United States, for example) with a legislation that qualified them as practices undermining free competition. In Germany, legislation for the protection of free competition was only adopted after the Second World War, when the labour movement was al ready well articulated.

Today, there is virtually no legal system that does not enshrine collective bargaining - as the foundation of a bal ance of forces in the labour market. At each level it is conducted (international - European - national - sector - local - unit), it determines the way labour relations are regulated and gives workers the opportunity to express themselves, through solidarity, with a unique voice Thus, for example, in our law, according to art 51 para. (5) of the Constitution, "the right to collective bargaining in labour matters and the binding nature of collective agreements shall be guaranteed". By this provision, Romania meets its obligations arising from the ratification of International Labour Organization Conventions 
(especially Convention no. 87/1948 on Freedom of Association and Protection of the Right to Organise and Convention no. 98/1949 concerning the Right to Organize and Collective Bargaining).

How is collective bargaining regulated? In essence, through collective bargaining itself. For example, collective agreements will also include rules on the next collective bargaining, which gives the system its autopoietic character. The system should be capable of self-generation.

Through collective bargaining, employees have the opportunity, by uniting their bargaining power to counter-balance the superior power of the employer, to determine the acceptance of (some of) the demands and the contractual regul ation of fair wages and working conditions, in relation to the possibilities and needs of each party. Beyond these premises, however, there is a whole universe of shades. In theory, the European neoliberal discourse began to question the social value of collective bargaining itself, considering it rather as a hindrance to economic development.

Currently, one cannot but notice that collective bargaining has indeed its limits, some circumstantial, others permanent. Collective bargaining takes place increasingly more timid and in rather marginal areas, its results covering a smaller number of employees. As traditional expression of the solidarity between workers, collective bargaining - while this solidarity displays signs of dissolution - has diminished its strength and shows a centrifugal, decentral ising tendency.

The regulatory scope reserved for collective labour agreements tends to shrink; they are being used mostly (as "defensive tools") to supplement the rights granted by law. The Romanian example is illustrative in this regard: the Social Dialogue Law no. 62/2011 eliminated the collective labour agreement at national level and reduced the role of collective bargaining agreements in general.

The effects are devastating. For example, during the economic crisis, the share of wages have declined, and the gross operating surplus increased, which leads directly to the conclusion that, in fact, the crisis was absorbed mainly by employees (Chivu et al., 2013: 37). Where was collective bargaining found in this process? Once the balance has been shaken, the trend is towards more pronounced imbal ance.

The contraction of collective bargaining does not manifest itself only in terms of categories of workers represented in the negotiations, but al so in terms of the topics of negotiation. As regards our legal system, the limitations to negotiation are obvious, especially in the public sector, where the main topic - wages and other pay rights - is expressly excluded from negotiation. 
And, indeed, the scope of collective bargaining tends to narrow, to the benefit of individual negotiation. This places the worker isolated in front of the employer, isolation sometimes determined by specific interests (which are not al ways the same with those of his colleagues), and other times by the legal impossibility of solidary action. It is not that it would not be useful, as useful as ever for employees, but it is the fact that certain social developments have obstructive effects on collective bargaining. And centrifugal and contracting tendencies on collective bargaining may jeopardize the very branch of labour law as a whole. Here, below, are some of the circumstances that can be considered responsible for the contracting tendency of collective bargaining.

\section{G lobalization}

Globalization has a significant impact on collective bargaining. Relocation of large industries in other countries has (in addition to the loss of jobs) the consequence of leaving an important gap in the trade union movement (Stone \& Cummings, 2013: 275). Moreover, employers can resist union pressure much better in conditions of gl obal ization, as they can easily relocate businesses in other regions of the world. And even when they do not follow on this threat, remaining in the original country, the very existence of this possibility at any time distorts the conduct of collective bargaining. Confronted with the threat of relocation, unions are sometimes reluctant to impose their demands, something that reinforces the public perception of their inefficiency. I have dealt more extensively on this elsewhere (Dimitriu, 2016: 270).

\section{Detailed legalization}

When social partners diminish their force, one of the first social reactions is (over) legalization. If employees and their unions do not have enough power to directly impose the recognition of certain interests on the employer, the law can do that directly. The more detailed regulations are, the less room is left for collective bargaining, especially in a system that does not allow derogation from the law unless it benefits the employees.

And, naturally, employees are voters. In this capacity, they may become interesting for those in power, who may confer certain rights directly (bypassing collective bargaining) by means of normative acts. Moreover, it thus becomes more lucrative for trade union leaders to engage in political struggle than in collective labour relations, as it may be easier to discuss with the government than with one's employer. 
But there is al so a catch here: the politicization of the trade union movement sooner or later leads to its being discredited. Association with one political party or another can be fruitful only on short-term Participation of trade unions in the political arena, be it manifest or covert, the numerous compromises without mandate from the workers and a certain general perception regarding their rather anti-reformist position led to a permanent dedine in popularity of trade union organizations.

However, legalization cannot achieve de plano the nuances of a collective agreement specifically adapted to the interests of those who have negotiated it. Moreover, the inclusion in the law of the rules of a collective agreement is most likely incomplete (and the most significant example for Romania is the national collective labour agreement the clauses of which were only taken up in part by the legislation at the time when it was abol ished by the Social Dial ogue Law).

In this context, a particular characteristic of collective agreements concluded here may also be mentioned: it has been noted that the instrument of collective bargaining was not always exploited creatively; many collective agreements at branch/sector level ended up reproducing the provisions of the law, of the National unique coll lective agreement, when it was in force, or perpetuating ol der contractual arrangements. Collective bargaining confines itself to extension of periods, adding paid leave days, superior rights, but on the exact same architecture already proposed by law, by higher level collective agreements or by older collective agreements. The consequence is that certain clauses, otherwise useful and easy to be accepted by employers, are missing from most collective agreements. They might concern, to give just one example, providing a dismissal notice which varies depending on the length of service in the unit (and therefore loyalty to it), or emphasizing the obligation of vocational training of employees at the expense of the employer.

Although, in theory, labour law is al so the result of a process of negotiation and it should involve wide consultations with the social partners, in fact it is the expression of political choices, often disconnected from any form of social dialogue.

\section{Competitive relations between workers}

In the traditional landscape of labour relations, employees are working shoulder to shoulder, pursuing interests that even if they are individual, they nonetheless share common features, working together for the good of the company and, ultimately, for their own benefit And, indeed, it can be said that competition rules cannot be (fully) implemented in the sphere of employment, because since labour is not a 
commodity, workers cannot be regarded as sellers of their workforce, who would compete with each other to get the price (wage) offered by the buyer (employer). Moreover, after condusion of the employment contract, the role of labour law is not only to distort market rules, by protecting the worker, but sometimes even to completely remove these rules. In other words, even if the selection of the applicants for employment has a certain competitive character, the competition can no longer continue after the conclusion of employment; workers could not be in competition with their colleagues, with people looking for a job or workers in precarious or seasonal jobs.

But in reality, this is exactly what is happening. The new management of human resources has an impact on the relations between workers who often perceive themselves as competitors. The consequence is that industrial relations get atomized while collective bargaining becomes impossible because internal competition undermines solidarity and therefore the inclination for joint action.

On the transnational level - the relation based on competition is even more evident The international ization of the labour market expands and amplifies the intensity of the competition. "Work is not a commodity" - is the assertion that is linked to the genesis of labour law. Today, however, it seems equally appropriate to say "Iabour law is not a commodity" (Conachan et al., 2005: XXVII), since gl obalization and the economic crisis often cause legal systems to lower the standards of protection of empl oyees, as competitive advantage.

In the European Union, for example, subsidies, tax breaks and other fiscal incentives to attract investment are in principle prohibited. European regulations prevent al most any instrument of this type. What can be done then to increase the level of attractiveness for investors? J ust one thing: lowering protection standards for workers in places where the intervention the union legislator is much more restricted.

The very concept of "social dumping" used in European labour law to support the need to impose certain standards of social protection for all workers - is reminiscent of competition. And internationally, beyond the borders of Europe, the practice of reducing labour law standards to create a competitive advantage becomes ever more present

This devel opment has led some authors to consider that labour law tends to turn in real ity into "social competition law" (Schubert, 2014: 29), putting the worker in a competitive position in relation to other workers, just like a company is in a position to compete against other companies. Which obviously affects solidarity and the possibility of collective bargaining; competitive relationships are not conductive to solidarity, which is seen as weakened not only at the international or national levels, but even at the level of a single establishment. 
Competition characterizes not only relations between employees, but also those between unions, which often act as entities competing in attracting members. And this has a certain impact on the trade uni on movement as a whole and on collective bargaining at higher levels - such as sector level.

Therefore, competitive relationships lead to the dissolution of solidarity between workers and, consequently, limit collective bargaining. But, as in a vicious circle, even where collective bargaining does take place, it can lead back to relationships that are even more competitive. Indeed, sometimes, collective bargaining, instead of directing towards reinforcing solidarity between workers, it has the effect of weakening it. Because what employees obtain by collective bargaining is not always a "victory" over the employer but over other employees. Collective bargaining is not al ways a regulator of relations between labour and capital, but it is often a means of redistributing resources among workers.

An example: imposing social criteria for selecting empl oyees in case of collective dismissals. Such a provision contained in the collective labour agreement would not diminish the number of employees laid off, but would just favour some employees to keep their jobs, with priority over others. Thus the distribution among workers of a certain disadvantage is negotiated, protecting some and exposing others; the employer may not bear any direct disadvantage.

Thus, during collective bargaining, instead of the classic question "Who will win the workers or the employer?" we have to deal with another question: "Who will win and who will lose among workers?"

The reality on which collective labour law was built is uniformity of interests at the workplace. Nevertheless, along with the diversification of employment and types of contracts this uniformity tends to end. There is a "hard core" of stable employees, surrounded by a mass of precarious, marginal workers not fully benefiting from the results of negotiation and therefore, they are neither interested in it (many not having proper employment contracts, but a variety of contractual arrangements of an uncertain legal nature).

Collective bargaining, therefore, no longer contains all workers in the company since an important part of them have their own interests, different or even impossible to reconcile with those of their colleagues (which, amid the dissolution of solidarity that I mentioned previously they often do not even perceive them as "colleagues").

Indeed, workers are no longer found in divergent relationships only with the employer, but also (and sometimes even primarily) with other workers, belonging to the same state or to other Member States of the European Union. The free 
movement of persons and the freedom of the provision of services determines workers not only be able to perform work in the territory of a Member State, but in the territory of any other Member State, and when the number of jobs is limited and the unemployment increasing, each worker is in fierce competition with any European worker. If some employees working for the same employer often perceive themselves as competitors, such positioning is even more pronounced when it comes to employees of other employers, operating under different legal systems, possibly subject to another legislation. The lack of solidarity that generated the Laval case (Case C-341/05) did not stop at the borders of trade union law or the practice of labour relations, but al so penetrated into the very theory of labour law, separating ideol ogists, separating approaches and even forcing theorists to take sides.

The Laval case is emblematic for the depth of the differences between the interests of workers in the old or the new Member States constituting (at a time when the European Union was still not facing the major dilemmas of today) a first alarm signalling that, under the appearance of a united Europe based on solidarity and mutual assistance lay hidden differences of interests, complex and perhaps even a certain amount of contempt

On another level, multiplication of hiring options and categories of workers (employees hired with atypical contracts, economically dependent workers, selfemployed etc.) amplified competitive relations among workers and shifted the centre of gravity of union activity.

Could the extension of collective bargaining be a solution? A broader negotiation that would involve not only employees, but also non-employees, raising their standards of protection and reducing this "negative" competition?

Indeed, many European systems of law began to allow unionisation of other categories of workers than employees, for example economically dependent workers: Austria, Denmark, Germany, Ireland, Italy, Lithuania, the Netherlands, Sweden and the UK. And some systems have gone even further than that, for example in Spain, the joumal ists' right to collective bargai ning is recognized, even if they do not have employee status. Similarly, in Germany, the law expressly provides the right of collective bargaining not only for employees, but also for "quasi-employees", i.e formally self-employed but economically dependent workers.

However, collective bargaining of non-employees encounters a number of obstacles in principle, starting with the representativeness of those who would negotiate on behalf of workers whose legal relationship is marked by its very uniqueness. In addition, significantly, collective bargaining could not cover 
workers who are legally and economically independent, as the Court of J ustice of the European Union held in Case C-413/13, since otherwise it would affect art. 101 para. (1) of the Treaty on the functioning of the European Union.

\section{The consumers' pressure}

When trade union demands concern all empl oyees of the establishment, so that the benefits that some of them get are not to the detriment of others, the employees claiming - and getting - superior rights applicable to all, at first glance it would seem that it is the employer who will have to pay the price of the concession made during collective bargaining.

But even in these cases, the costs of accepting the demands will likely be paid by consumers (who might be also workers that are equally disadvantaged economically like the ones for whom it was negotiated) rather than by the employer. Thus, some results of the collective bargaining perceived by workers as success stories may be viewed with reticence by consumers, customers, the general public; they will be compelled to buy more expensive products. Workers are also consumers; the price shall be carried on by the latter and the advantage of the former will only be apparent.

If the negotiation fails, a collective dispute is triggered which is generally seen as generating costs. Although any interuption of production is obviously harmful, often to both sides, one should bear in mind that reaching an agreement is not without costs either. While a strike will affect not only the parties in the collective dispute but also third parties (customers, consumers, beneficiaries, etc.), similarly, reaching a compromise and concluding a collective agreement could have repercussions on production costs and further on prices, thus affecting consumers.

\section{The opposition of employee-individual}

Collective bargaining, even if successful, results in the conclusion of a collective agreement, which will be applicable erga omnes at unit level and with relative applicability at higher levels. From the provisions of this collective agreement, employees may not derogate, during negotiation of the individual employment contract except for higher rights; derogation in pejus is prohibited in Romania (as in most other European systems of law). The collective labour agreement has on individual employment contracts concluded within its scope - a normative effect. 
In other words, collective contractual freedom is confined by the limits imposed by law; likewise individual contractual freedom is confined by the limits imposed by the collective bargaining agreement.

The possibility to derogate from the law in pejus by the collective agreement and from the provisions of the collective agreement by the individual contract is called "opting out" and constitutes an explicit consecration of the contractual freedom In our law, this possibility is recognized on one single occasion, namely regarding the reference period in relation to which the maximum limit of 48 hours per week is determined. Thus, art 114 para. (3) and (4) of the Labour Code sets out the right, through collective bargaining, to provide a reference period longer than the legal one (derogating therefore to the disadvantage of the employees). This capacity recognized to collective bargaining is singular in our law, and it was possi ble as the effect of the transposition of Directive 2003/88 conceming certain aspects of the organization of working time.

With this one exception, the derogation to the disadvantage of employees is prohibited in our law. There are, however, situations where this ban could still be regarded with reservations, for example:

- When individual interests do not overlap perfectly over collective ones. Thus, it is possible that an employee, at the individual level, may not be interested in a job security clause negotiated by the union in exchange for a lower level of wages than what employees would otherwise have been expected. A particular employee might not be interested in job security over a predetermined period of time, but he might be interested in getting a higher salary. Individually, he could ask for a higher salary, but even if he wanted to give up the security clause, it is applicable anyway. Likewise, the social selection criteria collectively bargained in the eventuality of collective redundancies may not meet the interests of a particular empl oyee who does not meet those social criteria;

- When a clause in the collective labour agreement is bilateral in nature, providing rights for both parties. For example, when the employer makes some concession to the employees in return for a corresponding concession on their part In French law, such clauses are considered indivisible, therefore they shall be considered together as more favourable or less favourable to the employee, in relation to all constituents (Adam, 2005: 319). In our law, the anal ysis is not gl obal, but on each component, each renunciation or concession in part coming from employees - is void, without this nullity necessarily attracting nullity of the reciprocal concession from the employer. Naturally, this approach is reflected on collective bargaining itself, which will take place in a narrower margin of freedom

The legislator thus seeks to privilege collective bargaining in relation to the individual one, a legitimate objective considering the general profile of labour law. 
And al so in a legitimate manner, the collective labour agreement treats workers as members of the community, absorbing their identity; it is not aimed at individual expectations, but is related to the community, which regards the worker in more abstract terms.

The employee-individual might be indined to manifest resistance against this system Indeed, on the altar of the "trade union struggle," workers have traditionally been taught to sacrifice their individual interests against those of the maj ority, thus subjecting themsel ves to a union democracy which usually does not preserve the identity of sub-groups and does not protect minorities. With time, this divergent relation between the union interest and the individual has undermined some of the force of the uni on, leading to some frustration among members, who saw their own personal interests (often more important to anyone than those of the group) under-represented or completely ignored.

And the result can be the lack of involvement itself of the employeeindividual in support of collective bargaining, with effects that can be multiplied in cascade.

\section{Diminishing E uropean collective bargaining}

From the foregoing analysis we have seen that there is a tendency to compress collective bargaining at all levels, decentralizing and narrowing it down to the individual employer. We can ask ourselves further if the European Union as an entity ontologically oriented toward solidarity, found formulas to counter this phenomenon, to support collective bargaining beyond the borders of each Member State.

First, it should be noted that the formal framework exists. The European Union recognizes the freedom of association and the right to collective bargaining as fundamental rights. Moreover, art. 154 of the Treaty on the functioning of the European Union provides the European Commission's task of promoting consul tation of the social partners at EU level and adopting any relevant measure to facilitate their dialogue by ensuring a bal anced support for the parties (Voiculescu \& Neagu, 2016: 93-95).

Following the acquisition of representativeness, the European social partners have the right to be consulted by the European Commission and may decide to negotiate binding agreements. The legal basis for this type of social dial ogue is found in the Treaty on the functioning of the European Union. Indeed, if the partners negotiate and conclude agreements at EU level, they are enforced by virtue of art. 155 para. (2) of the Treaty on the functioning of the European Union, in accordance with the procedures and practices of their own and those of the Member States (for 
comments on art 154-155 of the Treaty on the functioning of the European Union, R. Geiger et al., 2015: 646-649). In some areas, the agreement of the European social partners may result in a directive, which gives legal val ue at European level.

The social partners participate, besides consultations on relevant legislative proposals, at a biannual macroeconomic dialogue, as well as at discussions held twice a year at the high level Tripartite Social Summit.

Conceptually, cross-border collective bargaining can take place:

- at the level of an enterprise of European dimensions, leading to the adoption of collective agreements at the level of the enterprise (mega-employers, which employ at least 1,000 employees in the Member States and, in at least two different Member States, at least 150 empl oyees in each of them, are considered here);

- at branch level, with application in production units in the same industry but in several Member States, through trade union members of the same European confederations, or employers' organizations that belong to the same confederation, respectively;

- at EU level, with a view to concluding collective labour agreements between representative social partners at European level (Dimitriu et al., 2009: 31).

Annually over 200 European transnational company agreements are concluded in the EU, which would indicate that labour relations within large transnational companies in Europe have some degree of integration. Some transnational company agreements provided answers formulated at European level regarding the challenges posed by the crisis and have created mechanisms for managing change. Transnational company agreements al ready cover more than 10 million empl oyees. Noteworthy in this context is the adoption of social partner agreements generally applicable in the European Union, such as the Agreement on the development of lifelong skills and qualifications (2002) or the Telework Agreement (2002). Unlike previous agreements, which had been enforced by means of directives, these agreements had a direct and autonomous implementation.

Collective bargaining is even supported by a number of (embryonic) cross-border collective actions, including letters of support for trade union actions in a country by the trade unions formed in other countries or even solidarity strikes (or, more broadly, secondary collective actions). The Committee of Experts of the International Labour Organi sation has repeatedly criticized the legal systems which do not allow the organisation of such actions, which they consider necessary in a globalized economy and relocation of industrial centres (J aspers: 45). The right to take collective action and to conclude collective agreements constitute fundamental rights that are part of the general princi ples of European labour law. 
Indeed, cross-border collective action is considered the corollary of European social dialogue This was defined as:

(1) collective action involving or bearing on employees of two or more Member States or

(2) collective action carried out within a Member State, with reference to the employment relationships of employees in another Member State - in a spirit of cross-border solidarity (Bercusson, 2007: 8). Cross-border social dialogue is also supported beyond the territory of the European Union through the actions of the International Labour Organisation.

In the light of these prospects, it would have seemed natural that the next step should be the multiplication of collective labour agreements at transnational level and even the creation of a European collective labour law, based on generally applicable collective agreements. And yet, such a perspective is much more remote than it would seem

The reasons for scepticism as regards a future European negotiation can be identified in different directions:

- a large proportion of the provisions on labour relations exceed the regulatory power of the European Union. Against the background of a similar general vision of Member States, one encounters substantial differences, differing regulatory frameworks resulting from both objective factors (such as the relative novelty of European Union concerns in social matters) and the deliberate exclusion of certain topics from the preoccupations of the European Union (such as remuneration, the right of association, the right to strike or the right to impose lock-outs, remaining the exclusive competence of each Member State). The relatively small number of Directives and Regulations adopted in the fiedd of labour law is indeed proof that we are in an area where internal self-regulation is used to a greater extent than in other branches of law, the intervention of the European legislator being rather discreet;

- negotiation at European level is not sufficiently supported through European mechanisms involving the social partners, who in turn have an incipient character. Thus, "although the role of the social partners was institutionalized at European level, analyses show that they were not properly integrated into the decisionmaking process" (Szyszczak, 2006: 499). The reference to the social partners in the Treaty on the functioning of the European Union was considered as "rather vague" (Rodhes, 2005: 295), and their participation in the European Empl oyment Strategy has been generally acknowledged as "its weakest part" (Rodhes, 2005: 299);

- some institutions of representation, such as the Works Council, exist in some Member States (France, Germany), still missing in other Member States (including Romania); 
- the social partners themselves have evolved differently, have "internationalized" asymmetrically. In fact, there is a profound mismatch between the systematic internationalization of the capital and the predominantly national character of trade union organizations (Conachan et al., 2005: 381);

- the instrument correlative to the strike, namely the lock-out, is al lowed in some Member States and not in others. On the contrary, the strike, although permitted everywhere, can be organised in the most varied ways and according to the most diverse terms. As a result, even if the negotiation of collective agreements at European level were all owed, their failure to be finalized would not be able to lead simultaneously and in a similar way to collective action taken in different Member States;

- as mentioned previously, there is a relationship of competition between workers, which acts as an agent undermining solidarity, evidently at national level, but even more pronounced at European level. Such a relationship of competition among employees makes things more complicated and removes the possibility of effective collective bargai ning agreements;

- $\quad$ one of the main objectives of the trade unions in old Member States is antidumping policy, taking into account the practices of the workers from new Member States having penetrated the western labour market. Therefore the interests of western unions seem to collide with those of the workers from Central and Eastern Europe;

- even if such collective agreements at European level could actually be concluded, their effective implementation would be a substantial problem Agreements reached so far by the European social partners were then implemented in their own countries by means of internal instruments (legislative initiative and collective labour agreements).

Maybe for the reasons stated above, the European social dialogue, recognized as being part of the European Social Mode, is conducted rather shyly and mainly results in the adoption of documents without direct legally binding force (the socalled soft-law). Even in conditions of gl obal ization, it is stated firmly that even in the most developed economic regions of the world, the legal regime of collective labour relations is essentially national (Engels \& Weiss, 1998: 146-147).

The traditional relation, al ternating conflict and consensus, between employer and employees, internally but also at European level, is coupled with a new type of relation, in tum consensual and conflictual: between workers belonging to different Member States. They are competing for a limited number of jobs. It may be a theme for reflection for unions as well, since the objective of European trade union solidarity seems more distant than ever.

Here's one example: manifestations against austerity policies, even though they had a common background and were generated by the same decisions taken at 
European level, remained circumscribed to national territories. Even when such policies have directly addressed employment relations (leading for example to wage cuts) they could not generate transnational union movements or strikes, among other things because the legal regime for resolution of collective disputes is so different from state to state. Solidarity is not only difficult psychologically and socially, but also restricted legally. The transnational strike still remains a theoretical possibility. Collective labour law remains - alas! - deeply rooted in the national sphere and al most insensitive to the phenomenon of European integration.

\section{Conclusions}

The particularity of labour law compared to other branches of law is that, along with legal sources, it has negotiated sources. The latter is not the result of the manifestation of the will of the legislator, but of collective bargaining meant to lead to an agreement of wills between the social partners. It is about contracts and collective agreements - contractual sources of collective labour law - as results of collective bargaining. The dual nature of the source of labour law is the one which al ways shaped the identity of this branch of law. It would seem, however, that we are witnessing a return of labour law to the "individual", an abandonment of the collective (and collectivist) underpinning of labour law with a direct and unfortunate impact on collective bargaining.

Thus, the issue of collective bargaining is high on the agenda throughout the European and American literature on labour law. It is thus noted that collective bargaining is constantly focused on pay and redundancies, rarely having regard to other interests, such as the human need for self-affirmation, respect and dignity at work (Collins, 1998: 117). These interests remain problems managed by individual negotiation or, worse off, left entirely to the management A gai nst this background, the fundamental legitimacy of the collective bargai ining seems to be questioned.

In this context, in turn, globalization, digitalization, competitive relations between workers, pressure from consumers, the increasingly significant image deficit experienced by unions (traditional exponents of employees in collective bargaining), the dissolution of solidarity between workers at national but also European level - led to a contraction (collapse) of collective bargaining to disturbing levels.

\section{Acknowledgment}

This paper was presented at the International conference AMIS 2017, held at the Bucharest University of Economic Studies, Romania, in the Law Section. 


\section{R eferences}

Adam P. (2005) L'individualisation du droit du travail, Librairie Générale de Droit et de J urisprudence, Paris

Bercusson, B. (2007) "Restoring Balance of Economic Power in Europe”, in F. Dorssemont, T. Jaspers, A. Van Hoek (eds.), Cross-Border Collective Actions in Europe: a Legal Chalenge, Ed. Intersentia, Antwerpen-Oxford

Chivu L., Ciutacu C., Dimitriu R., Țiclea T. (2013) The Impact of Legislative Reforms on Industrial Relations in Romania, ILO, Decent Work Technical Support Team and Country office for Central and eastern European Industrial and employment Relations DepaRTmenT (DiaLogue)

Collins, H. (1998) „Flexibility and Empowerment”, in T. Wilthagen (coord.), Advancing Theory in Labour Law and Industrial Relations in a Global Context, Royal Netherland Academy of Arts and Science, Amsterdam

Conachan, J., Fischl, R.M., Klare K. (coord.) (2005) Labour Law in an Era of Globalization. Transformative Practices \& Possibilities, Oxford University Press

Däubler, W., (2014) "Labour Law and Competition", in Rigaux, M., Buelens, J., Latinne, A., (eds), From Labour Law to Social Competition Law?, Ed. Intersentia

Dimitriu R. (2016) Dreptul muncii. Anxietăți ale prezentului, Bucureşti: Ed. Rentrop şi Straton

Dimitriu, R., Vartolomei, B., Vidat, A., (2009) „Negocierea colectivă şi protecția lucrătorilor migranți în cadrul Uniunii Europene", Romanian Review of Labour Law, no. 5: 24-35

Engels, C. \& Weiss, M., (eds), (1998) Labour Law and Industrial Relations at the Turn of the Century, Deventer - Boston, Kluwer Law International

Geiger, R., Khan, D-E , Kotzur M. (coord.) (2015) European Union Treaties, CH Beck, Hart, Germany

Hendrickx, F. (2010) „The future of collective labour law in Europe”, European Labour Law J ournal, no. 1: 59-79

Jaspers, A. (2007) "The right to collective action in European Law", in F. Dorssemont, T. Jaspers, A. Van Hoek (eds.), Cross-Border Collective Actions in Europe: a Legal Chalenge, Ed. Intersentia, Antwerpen-Oxford

Rodhes, M., (2005) „Employment Policy: Between Efficacy and Experimentation”, in H. Wallace, W. Wallace and M. Pollack (eds.), Policy-Making in the European Union, Fifth Edition, Oxford: Oxford University Press

Schubert, J.M. (2014) „Instruments of Labour Law”, in Rigaux, M., Buelens, J., Latinne, A., (eds), From Labour Law to Social Competition Law?, Ed. Intersentia

Stone, K. \& Cummings, S. (2013) "Labour Activism in Local Politics", In Davidov, G. \& Langille, B. (coord.) The Idea of Labour Law, Oxford University Press 
Szyszczak, E. (2006) „Experimental Governance: The Open Method of Coordination", European Law J ournal, vol. 12, no. 4: 486-502

Ştefănescu, I.T. (2014) Tratat teoretic şi practic de drept al muncii, Ed. Universul Juridic, Bucure $\square$ ti

Voiculescu, N. \& Neagu, V. (2016) Protecția drepturilor lucrătorilor în dreptul internațional şi european, Ed. Universitară 